\title{
PEMANTAPAN NILAI-NILAI KEBANGSAAN BAGI ETNIS TIONGHOA
}

\author{
Kurnia Setiawan $^{1}$, Ninawati ${ }^{2}$ dan Meiske Yunithree ${ }^{3}$ \\ ${ }^{1}$ Fakultas Seni Rupa dan Desain, Universitas Tarumanagara Jakarta \\ Email:kurnias@fsrd.untar.ac.id \\ ${ }^{2}$ Fakultas Psikologi, Universitas Tarumanagara Jakarta \\ Email: ninawati@fpsi.untar.ac.id \\ ${ }^{3}$ Fakultas Psikologi, Universitas Tarumanagara Jakarta \\ Email: meiskey@fpsi.untar.ac.id
}

\begin{abstract}
Pancasila values need to be understood and practiced in everyday life. The INTI (Indonesian Chinese) Association conducts training on "Consolidating Pancasila Values (Taplai)". The joint Taplai activity of Chinese organizations was the first to be held. This study wanted to find out whether the Taplai Training could increase the knowledge, understanding and nationalistic attitudes of the training participants. The socialization of the Taplai activity was conducted in front of 13 organizations from various Chinese organizations, businessmen, professionals, and several non-Chinese representatives. The research used a mixed method of quantitative and qualitative through distributing questionnaires pre-test and post-test, observation and interviews. Based on the results of data collection through questionnaires and interviews from 91 participants, it can be concluded that the Taplai training can increase knowledge about the values of Pancasila and foster a sense of nationality. In general, all subjects understood national values that refer to the four pillars, namely Pancasila, UUD 1945, Bhinneka Tunggal Ika and NKRI, several participants who were interviewed all gave positive testimonies about the experience and benefits of the Taplai training for them.
\end{abstract}

Keywords: the values of a nationality, Tionghoa ethnic, Taplai, Perhimpunan INTI

\begin{abstract}
ABSTRAK
Nilai-nilai Pancasila perlu dipahami dan diamalkan dalam kehidupan sehari-hari, Perhimpunan INTI (Indonesia Tionghoa) melaksnakan pelatihan "Pemantapan Nilai-Nilai Pancasila (Taplai)". Kegiatan Taplai gabungan organisasi Tionghoa merupakan yang pertama kali diadakan. Penelitian ini ingin mengetahui apakah Pelatihan Taplai dapat meningkatkan pengetahuan, pemahaman dan sikap nasionalisme peserta pelatihan. Sosialisasi kegiatan Taplai di hadapan 13 organisasi yang berasal dari berbagai organisasi Tionghoa, pengusaha, profesional, dan beberapa perwakilan non Tionghoa. Penelitian menggunakan metode campuran antara kuantitatif dan kualitatif melalui penyebaran kuesioner pre-test dan post-test, observasi serta wawancara. Berdasarkan hasil pengumpulan data melalui kuesioner dan wawancara dari 91 peserta, dapat disimpulkan pelatihan Taplai dapat meningkatkan pengetahuan tentang nilai-nilai Pancasila dan menumbuhkan rasa kebangsaan. Pada umumnya semua subyek memahami tentang nilai-nilai kebangsaan yang mengacu pada empat pilar, yaitu Pancasila, UUD 1945, Bhinneka Tunggal Ika dan NKRI, beberapa peserta yang diwawancara semua memberikan kesaksian yang positif tentang pengalaman dan manfaat pelatihan Taplai bagi mereka.
\end{abstract}

Kata kunci: nilai-nilai kebangsaaan, etnis Tionghoa, Taplai, perhimpunan INTI

\section{PENDAHULUAN Latar Belakang}

Presiden Susilo Bambang Yudhoyono pada tahun 2006 menerbitkan Undang-Undang kewarganegaraan yang baru, yakni Undang-Undang nomor 12 tahun 2006 tentang "Kewarganegaraan Republik Indonesia". Dengan Undang-Undang ini, warga Tionghoa ditempatkan dalam posisi yang sama/setara dengan warga negara yang lain. Artinya, perbedaan antara "pribumi" dan "non-pribumi" - seperti yang terjadi sebelumnya -- tidak berlaku lagi (Thung dalam Chang, 2012). Masyarakat Tionghoa, setelah era reformasi juga terjadi "kegairahan" - kebangkitan kasadaran politik, salah satu bentuknya adalah organisasi sosial 
kemasyarakatan yang bertujuan memperjuangkan kepentingan masyarakat Tionghoa. Seperti Perhimpinan Tionghoa Indonesia (INTI) (Budianta dalam Dawis, 2010).

Perhimpunan Indonesia Tionghoa dideklarasikan pada tanggal 10 April 1999 adalah organisasi yang bersifat kebangsaan sesuai semangat mukadimah UUD NKRI 1945, bebas, egaliter, pluralis, demokratis, tidak bernaung atau mengikatkan diri kepada salah satu partai politik dan terbuka bagi semua Warga Negara Indonesia yang setuju dengan Anggaran Dasar, Anggaran Rumah Tangga, serta Tujuan Perhimpunan INTI. Dari sekitar 400 organisasi Tionghoa di Indonesia, INTI tampil berbeda dengan ciri kebangsaan dan nasionalisme. INTI mengajak segenap organisasi Tionghoa untuk mengikuti program "Pemantapan Nilai-Nilai Kebangsaan" (Taplai) bagi Perhimpunan Indonesia Tionghoa. Peserta berasal dari organisasi Tionghoa, pengusaha, profesional, dan perwakilan non Tionghoa.

Berkembangnya perhimpunan INTI tidak terlepas karena dukungan situasi sosial politik yang berubah sejak pasca era reformasi. Perubahan penting di tingkat politik nasional, misalnya, adalah apa yang dilakukan Presiden Abdurrahman Wahid ketika beliau menerbitkan Inpres Nomor 6 pada tahun 2000 yang membatalkan peraturan sebelumnya (ada sejak 1967) yang melarang "ekspresi" kebudayaan Cina di ruang publik (Wibowo \& Thung, 2010). Presiden Megawati - melalui Keputusan Presiden Nomor 19 tahun 2002 - juga ditetapkan perayaan Tahun Baru Imlek sebagai hari libur nasional (Wibowo \& Thung, 2010).

Melalui kesempatan kerjasama dengan Lembaga penyelenggara Taplai di tingkat Nasional, INTI mengajak segenap organisasi Tionghoa untuk mengikuti program "Pemantapan Nilai-Nilai Kebangsaan" (Taplai) bagi Perhimpunan Indonesia Tionghoa. Peserta berasal dari organisasi Tionghoa, pengusaha, profesional, dan perwakilan non Tionghoa. Taplai dilaksanakan dengan menggunakan metode pelatihan di dalam ruangan dengan cara tutorial dan seminar selama lima hari, dan dua hari dilakukan outbound di lapangan terbuka. Para trainer/ instruktur dan peserta yang terdiri dari organisasi Tionghoa, pengusaha, profesional, dan perwakilan non Tionghoa berproses bersama selama kegiatan Taplai dan memunculkan pengalaman baru bersama.

Proses belajar ini dapat dikatakan adalah metode social-constructivist, yang menekankan pada konteks sosial dalam belajar dan sebuah ide yang mengatakan bahw ailmu pengetahuan dibentuk dan dikonstruksi dari lingkungan sosial Vygotsky (dalam Santrock, 2011) mengatakan bahwa guru (dalam konteks taplai adalah instruktur) sebaiknya menciptakan bersama. Kegiatan taplai dimulai dari lingkungan sosial kebutuhan etnis Tionghoa dalam meningkatkan pemahaman dan pemantapan tentang nilai-nilai Pancasila. Kegiatan taplai merupakan proses belajar dalam rangka menambah pengetahuan dan pengalaman. Salah satu strategi pembelajaran adalah pembelajaran kontekstual yang menekankan pada proses secara penuh untuk dapat menemukan materi yang dipelajari dan menghubungkan dengan situasi kehidupan nyata, sehingga mendorong siswa/peserta untuk dapat menerapkannya dalam kehidupan mereka (Sanjaya, 2008).

Pendapat lain tentang Contextual Teaching Learning memotivasi peserta didik untuk bertanggung jawab atas pembelajaran mereka sendiri dan untuk menghubungkan antara pengetahuan dan aplikasinya dalam berbagai konteks kehidupan mereka (Satriani, et al., 2012). Pelatihan Taplai merupakan proses pembelajaran dengan mengusung tema khusus yang menekankan keterlibatan peserta dan instrukturnya. Mulyani dan Farida (2020) mengatakan bahwa pembelajaran tematik harus menghubungkan materi situasi nyata siswa dalam kehidupan 
masyarakat di mana mereka menjalani kehidupannya. Metode eksperimental dalam proses pembelajaran digunakan untuk menerapkannya.

Proses belajar atau pemahaman tentang sesuatu (pengetahuan) ditunjukkan dengan ada tidaknya peningkatan hasil belajar dalam ranah kognitif dan keterampilan proses pengetahuan, yang dikenal dengan pembelajaran inkuiri melalui metode eksperimen (Subekti \& Ariswan, 2016). Pendapat yang serupa dikemukakan oleh Gartini (2016) dari hasil penelitiannya terhadap siswa Sekolah Dasar. Hasil penelitiannya menunjukkan bahwa pembelajaran inkuiri sosial berpengaruh secara signifikan terhadap peningkatan keterampilan berpikir kritis siswa. Sementara itu penelitian Suherman (2013) menunjukkan ada peningkatan hasil belajar siswa pada ranah kognitif, ranah psikomotor, dan ranah afektif dengan menggunakan model pembelajaran Problem Solving berbasis Eksperimen.

Melalui penelitian ini proses kegiatan Taplai direkam dan dikaji, terutama hal yang berkaitan dengan perubahan yang terjadi pada peserta sebelum dan sesudah mengikuti kegiatan tersebut. Penelitian ini melihat perubahan pemahaman/ sikap dari kalangan orang Tionghoa. Setelah era Orde Baru berakhir, muncul berbagai peluang dan kesempatan bagi etnis Tionghoa untuk mengekspresikan dan mengembang diri/ kelompoknya. Adapun kadangkala muncul kecurigaan keraguan pada nasionalisme etnis Tionghoa. Melalui penelitian ini dapat dikaji secara ilmiah pengetahuan, pandangan, dan sikap etnis Tionghoa tentang nilai-nilai kebangsaan dan semangat nasionalisme.

Penelitian ini ingin mengetahui bagaimana proses yang terjadi sehubungan dengan kegiatan Taplai yang dilaksanakan bagi khalayak sasaran? Apakah para peserta mengalami perubahan pengetahuan/ pemahaman/ sikap setelah mengikuti kegiatan tersebut? Penelitian ini mencoba menjawab pertanyaan tersebut, melalui wawancara, observasi dan penyebaran kuesioner yang diberikan sebelum dan sesudah kegiatan dilaksanakan

\section{METODE PENELITIAN}

\section{Partisipan dan Prosedur Penelitian}

Penelitian ini menggunakan metode campuran kuantitatif dan kualitatif, dengan melibatkan 91 orang subyek penelitian sebagai responden dan beberapa perwakilan peserta untuk diwawancara. Subyek penelitian yang bertindak sebagai partisipan dipilih dengan metode purposive sampling, yaitu subyek yang dipilih berdasarkan kriteria tertentu, yaitu perwakilan para peserta pelatihan "Pemantapan Nilai-Nilai Kebangsaan" Bagi Perhimpunan Indonesia Tionghoa. Peserta Taplai berjumlah 99 orang, namun yang dapat dijadikan subyek penelitian hanya 91 orang, karena 8 orang tidak mengembalikan kuesioner awal atau kuesioner akhir. Pelatihan dilaksanakan selama 7 hari. Lima hari pertama kegiatan dilakukan di gedung LRI, Jakarta dan 2 hari terakhir aktivitas outbound di Cikreteg Bogor.

\section{Instrumen Penelitian}

Instrumen penelitian yang digunakan adalah: alat perekam gambar dan suara, peralatan tulis, dan keperluan pelengkapnya. Adapun untuk pertanyaan yang diajukan kepada subyek berupa kuesioner diberikan sebelum dan sesudah kegiatan pelatihan. Selain dengan wawancara, pengumpulan data dilakukan dengan observasi lapangan melalui pengamatan para pendampinhg proses.

Analisis data dilakukan dengan verbatim transkripsi untuk hasil penelitian yang dilakukan melalui wawancara. Hasil verbatim transkripsi ini kemudian dibuatkan analisis dan digabungkan 
dengan hasil pengamatan panitia pendamping. Kuesioner dihitung perbedaan pemahaman tentang nilai-nilai Pancasila sebelum dan setelah mengikuti pelatihan

\section{HASIL DAN PEMBAHASAN}

Subyek dalam penelitian ini adalah peserta pelatihan yang diselenggarakan pada tanggal $28 \mathrm{Juli}-$ 5 Agustus 2018. Subyek penelitian yang dipergunakan untuk analisis adalah subyek yang mengikuti pelatihan secara menyeluruh atau lengkap. Artinya subyek penelitian sebelum mengikuti pelatihan diberikan kuesioner dan setelah pelatihan diberikan kembali kuesioner yang sama, hal ini dilakukan untuk mengukur efektivitas keikutsertaan subyek dalam pelatihan tersebut. Subyek yang mengisi kuesioner sebelum pelatihan berjumlah 96 orang, namun yang mengikuti pelatihan secara keseluruhan berjumlah 91 orang. Sementara itu ada enam orang subyek yang mengisi kuesioner pada bagian akhir pelatihan tetapi tidak mengisi kuesioner pada sebelum pelatihan. Dengan demikian ada sebelas orang subyek yang datanya tidak dapat diikutsertakan dalam analisis selanjurnya.

Berdasarkan asal tempat tinggal, subyek terbanyak berasal dari Jakarta (31 orang atau 34,1\%), urutan kedua Medan (16 orang atau 17,6\%), selebihnya tersebar dari beberapa kota di Pulau Jawa, Bali, Sumatera, Kalimantan, dan Sulawesi. Data selengkapnya dapat dilihat pada lembar Lampiran). Berdasarkan usia subyek, yang termuda berusia 21 tahun yang paling tua berusia 75 tahun. Pada tabel berikut disusun usia subyek yang telah dikelompokkan. Pada kelompok usia 31-40 tahun terdapat 25 subyek (27,5\%). Sesuai dengan tujuan diselenggarkannya pelatihan ini, yang menjadi sasaran adalah generasi muda, maka subyekpun berusia di bawah 40 tahun.

Tabel 1. Usia subyek

\begin{tabular}{lcc}
\hline Usia (tahun) & Jumlah subyek & Persentase \\
\hline $21-30$ & 21 & 23,1 \\
$31-40$ & 25 & 27,5 \\
$41-50$ & 17 & 18,7 \\
$>50$ & 24 & 26,4 \\
Tidak mengisi & 4 & 4,4 \\
\hline Jumlah & 91 & 100,0 \\
\hline
\end{tabular}

Kegiatan subyek dalam kehidupan sehari-hari berbeda-beda. Ketika mereka ditanya tentang latar belakang kegiatan mereka paling banyak adalah organisasi, berjumlah 52 subyek $(57,1 \%)$ yang menjawab hal ini. Urutan berikutnya adalah pengusaha terdiri dari 32 subyek $(35,1 \%)$. Data selengkapnya dapat dilihat pada tabel berikut.

Tabel 2. Latar belakang subyek

\begin{tabular}{lcc}
\hline Latar belakang & Jumlah subyek & Persentase \\
\hline Organisasi & 52 & 57.1 \\
Pengusaha & 32 & 35.2 \\
Profesional & 4 & 4.4 \\
Karyawan & 3 & 3.3 \\
\hline Jumlah & 91 & 100,0 \\
\hline
\end{tabular}

Pada pertanyaan tentang harapan subyek mengikuti kegiatan pelatihan, diberikan jawaban multi respon, sehingga seorang subyek dapat mengisi lebih dari satu jawaban. Dengan demikian jumlah jawaban melebihi jumlah subyek seluruhnya, namun perhitungan persentase dilakukan terhadap 91 subyek yang mengisi kuesioner. Dari tabel tersebut terlihat harapan subyek 
mengikuti pelatihan ini adalah "menambah pengetahuan tentang nilai kebangsaan" dipilih oleh 79 subyek (86,81\%). Pilihan kedua terbanyak adalah "menambah jejaring" yang dipilih oleh 30 subyek (32,97\%). Data selengkapnya dapat dilihat pada tabel 3.

Tabel 3. Harapan subyek mengikuti kegiatan pelatihan

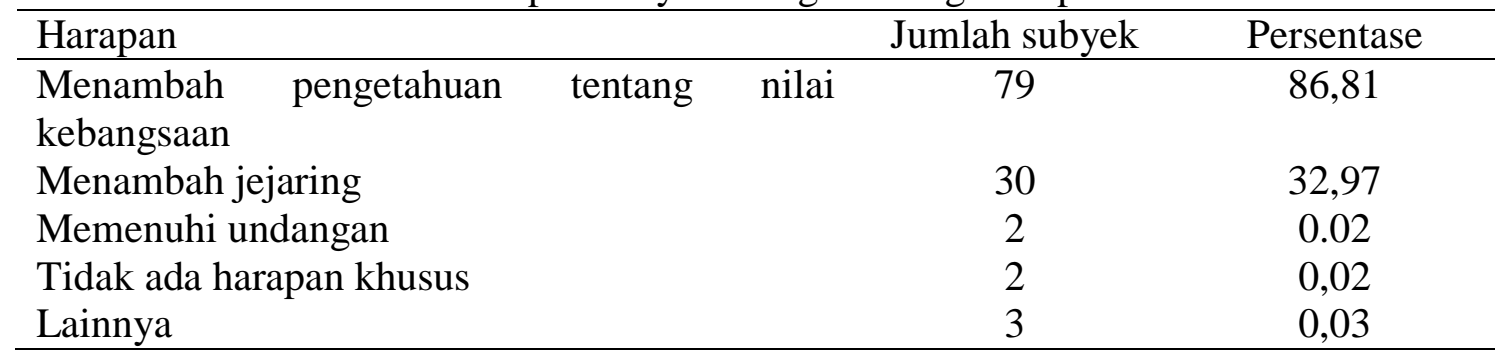

Pelatihan ini bertujuan untuk meningkatkan pengetahuan peserta tentang nilai-nilai Pancasila yang telah dikenal dan diketahuinya. Adapun pertanyaan yang diajukan berjumlah 13 butir dengan bentuk pertanyaan semi terbuka yang memberikan kebebasan subyek untuk menuliskan pendapatnya, yaitu:

1. Apakah Anda mengetahui tentang nilai-nilai kebangsaan?

2. Apakah Anda tahu peranan Etnis Tionghoa dalam sejarah Indonesia?

3. Apakah Anda tahu implementasi nilai kebangsaan yang bersumber dari Pancasila?

4. Apakah Anda tahu implementasi nilai kebangsaan yang bersumber dari UUD 1945?

5. Apakah Anda tahu implementasi nilai kebangsaan yang bersumber dari sesanti Bhinneka Tunggal Ika?

6. Apakah Anda tahu implementasi nilai kebangsaan yang bersumber dari NKRI?

7. Apakah Anda tahu tentang apa yang dimaksud dengan lingkungan strategis dalam kehidupan bermasyarakat, berbangsa dan bernegara?

8. Apakah Anda tahu implementasi wawasan nusantara dalam kehidupan bermasyarakat, berbangsa dan bernegara?

9. Apakah Anda tahu implementasi ketahanan nasional dalam kehidupan bermasyarakat, berbangsa dan bernegara?

10. Apakah Anda tahu implementasi kewaspadaan nasional dalam kehidupan bermasyarakat, berbangsa dan bernegara?

11. Apakah Anda tahu implementasi kepemimpinan nasional dalam kehidupan bermasyarakat, berbangsa dan bernegara?

12. Apakah Anda tahu tentang revolusi mental?

13. Apakah Anda tahu tentang kepemimpinan dan manajemen bela negara?

Dari 13 butir pertanyaan dibuat nilai rata-rata sebelum mengikuti pelatihan dan setelah pelatihan. Adapun nilai rata-rata pengetahuan tentang nilai Pancasila yang diperoleh sebelum pelatihan adalah 1,5182 naik menjadi 1,9070 setelah mengikuti pelatihan. Adapun cara memberikan penilaian tentang pengetahuan subyek diberikan antara nilai 1 untuk tidak tahu, dan nilai 2 untuk tahu. Dengan demikian dapat dikatakan bahwa pengetahuan subyek sebagian besar berubah dari tidak tahu menjadi tahu, setelah mengikuti pelatihan. Kemudian perbedaan nilai rata-rata ini diuji secara statistik, mendapatkan nilai signifikansi 0.000. Artinya, pelatihan ini menambah nilai pada pengetahuan subyek terkait dengan nilai-nilai Pancasila. Tabel 4 berikut ini memuat nilai-nilai tersebut, perhitungan dan hasil output uji statistika terdapat pada lembar lampiran. 
Tabel 4. Persepsi subyek tentang nilai-nilai Pancasila

\begin{tabular}{llc}
\hline Persepsi & Mean & Standar deviasi \\
\hline Sebelum pelatihan & 1,5182 & 0,36349 \\
Setelah pelatihan & 1,9070 & 0,2286 \\
\hline
\end{tabular}

Setelah melakukan pengujian statistika dengan metode T-Test dan diperoleh hasil yang signifikan, maka pengujian diteruskan untuk masing-masing butir pertanyaan. Hasilnya menunjukkan semua hasil ujinya signifikan, artinya ada perbedaan antara nilai sebelum pelatihan dengan nilai setelah pelatihan. Tabel 5 berikut ini merinci hasilnya.

Tabel 5. Persepsi subyek tentang nilai-nilai Pancasila untuk masing-masing butir

\begin{tabular}{|c|c|c|}
\hline Butir & $\begin{array}{l}\text { Mean sebelum } \\
\text { pelatihan }\end{array}$ & $\begin{array}{l}\text { Mean sesudah } \\
\text { pelatihan }\end{array}$ \\
\hline Nilai-nilai kebangsaan & 1,7582 & 1,9231 \\
\hline $\begin{array}{l}\text { Peranan Etnis Tionghoa dalam sejarah } \\
\text { Indonesia }\end{array}$ & 1,6923 & 1,9560 \\
\hline $\begin{array}{l}\text { implementasi nilai kebangsaan yang bersumber } \\
\text { dari Pancasila }\end{array}$ & 1,6703 & 1,9341 \\
\hline $\begin{array}{l}\text { Implementasi nilai kebangsaan yang bersumber } \\
\text { dari UUD } 1945\end{array}$ & 1,5275 & 1,9451 \\
\hline $\begin{array}{l}\text { Implementasi nilai kebangsaan yang bersumber } \\
\text { dari sesanti Bhinneka Tunggal Ika }\end{array}$ & 1,6264 & 1,9121 \\
\hline $\begin{array}{l}\text { Implementasi nilai kebangsaan yang bersumber } \\
\text { dari NKRI }\end{array}$ & 1,5275 & 1,9011 \\
\hline $\begin{array}{l}\text { Lingkungan strategis dalam kehidupan } \\
\text { bermasyarakat, berbangsa dan bernegara }\end{array}$ & 1,3516 & 1,8901 \\
\hline $\begin{array}{l}\text { Implementasi wawasan nusantara dalam } \\
\text { kehidupan bermasyarakat, berbangsa dan } \\
\text { bernegara }\end{array}$ & 1,3956 & 1,9121 \\
\hline $\begin{array}{l}\text { Implementasi ketahanan nasional dalam } \\
\text { kehidupan bermasyarakat, berbangsa dan } \\
\text { bernegara }\end{array}$ & 1,4066 & 1,9011 \\
\hline $\begin{array}{l}\text { Implementasi kewaspadaan nasional dalam } \\
\text { kehidupan bermasyarakat, berbangsa dan } \\
\text { bernegara }\end{array}$ & 1,4615 & 1,8791 \\
\hline $\begin{array}{l}\text { Implementasi kepemimpinan nasional dalam } \\
\text { kehidupan bermasyarakat, berbangsa dan } \\
\text { bernegara }\end{array}$ & 1,3846 & 1,8791 \\
\hline Revolusi mental & 1,5934 & 1,9231 \\
\hline Kepemimpinan dan manajemen bela negara & 1,3407 & 1,8352 \\
\hline
\end{tabular}

Pada tabel 5 terlihat nilai pengetahuan subyek sebelum dan sesudah mengikuti pelatihan mengalami kenaikan pada semua butir pertanyaan yang diajukan. Jika dilihat pada masingmasing butir, maka butir tujuh mendapatkan nilai kenaikan paling tinggi. Pengetahuan subyek tentang lingkungan strategis dalam kehidupan bermasyarakat, berbangsa, dan bernegara sebelum pelatihan adalah 1,3516 mendapatkan kenaikan sebesar 0,5385 menjadi 1,8901. Sedangkan kenaikan terkecil ditemukan pada butir pertama tentang nilai-nilai kebangsaan, hanya mendapat kenaikan 0,1649 hal ini terjadi karena butir nomor 1 ini sebelum pelatihan telah mendapat nilai yang tinggi yaitu sebesar 1,7582 naik menjadi 1,9231 . 
Peningkatan nilai pemahaman dari hasil pelatihan ini mendukung pendapat yang ditemukan dalam penelitian sebelumnya, baik yang terkait dengan proses belajar maupun metode pelatihan yang diterapkan. Proses belajar dalam pelatihan ini terkait dengan social-constructivist, yang melibatkan kegiatan bersama antara instruktur dan peserta pelatihan (Vygotsky dalam Santrock, 2011). Proses pelatihan menggunakan pembelajaran kontesktual yang melibatkan pengalaman dalam kehidupan nyata seperti diungkapkan oleh Sanjaya (2008) dan (Satriani, et al., 2012).

Berdasarkan metode pelatihan yang menggunakan eksperimen (within subject) dengan subyek yang sama tetapi diukur sebelum dan setelah pelatihan terbukti efektif meningkatkan pengetahuan dan pemahaman tentang nilai-nilai kebangsaan (Pancasila). Metode ini dipakai dalam beberpa penelitian yang terkait dengan pembelajaran tematik (Mulyani \& Farida, 2020). Proses belajar atau pemahaman tentang sesuatu (pengetahuan) dalam ranah kognitif atau proses pembelajaran inkuiri dilakukan dengan metode eksperimen seperti hasil penelitian Suherman (2013), Subekti dan Ariswan (2016), Gartini (2016).

\section{KESIMPULAN DAN SARAN}

Kesimpulan dalam penelitian ini adalah:

1. Subyek telah mengikuti pelatihan dengan sungguh-sungguh, sehingga diperoleh hasil uji sebelum dan sesudah pelatihan memberikan nilai perubahan yang signifikan kea rah positif, yaitu semakin bertambah pemahaman tentang nilai-nilai kebangsaan (Pancasila).

2. Pelatihan untuk meningkatkan pengetahuan tentang nilai-nilai Pancasila, dapat dikatakan berhasil karena pengetahuan dan persepsi tentang nilai-nilai Pancasila diperoleh peningkatan dari seluruh butir yang diujikan. Proses belajar yang melibatkan ranah kognitif memerlukan penerapan dalam kehidupan dan pengalaman bermasyarakat demikian pula untuk memahami sesuatu perlu melibatkan pembelajaran kontekstual yang terkait dengan social-constructivist.

3. Berdasarkan wawancara dari beberapa perwakilan peserta (dari perwakilan daerah, pengusaha, orang tua, dan peserta Taplai tertua dan termuda) hasil dari pelatihan yang mereka ikuti antara lain: Taplai membangun nilai kebangsaan dan identitas diri, percaya diri jadi NKRI, berkontribusi bangun bangsa, membuka pikiran anak muda bangun rasa kebangsaan, meresapi jiwa dan tebarkan rasa kebangsaan.

Kegiatan pelatihan Taplai perlu terus dilaksanakan, sehingga makin mempererat persaudaraan dan menumbuhkan rasa kebangsaan. Komposisi peserta Taplai INTI dapat tetap dipertahankan ada unsur perwakilan dari orang/ kelompok di luar INTI untuk mengembangkan jejaring dan menumbuhkan solidaritas sehingga di kemudian hari dapat berkerjasama antar kelompok.

\section{Ucapan Terima Kasih}

Kami mengucapkan terima kasih untuk semua pihak yang telah mendukung penelitian ini, DPPM Untar, Perhimpunan Indoensia Tionghoa, dan seluruh pihak yang telah berkontribusi sehingga penelitian ini dapat dilaksanakan.

\section{REFERENSI}

Chang, Y. H (2012). Identitas Tionghoa Pasca Soeharto - Budaya, Politik dan Media, Jakarta: LP3ES

Dawis, A. (2010). Orang Indonesia Tionghoa - Mencari Identitas. Jakarta: Gramedia.

Gartini, N. (2016). Pengaruh penerapan pembelajaran inkuiri social terhadap keterampilan berpikir siswa SD (Studi Eksperimen Kuasi pada Pembelajaran Ilmu Pengetahuan Sosial). Jurnal Pendidikan Ilmu Sosial, 25(2), 41-47. 
Mulyani, S., \& Farida, F. (2020). Pengembangan LKPD berorientasi eksperimen dalam pembelajaran tematik terpadu di Sekolah Dasar. Jurnal Basicedu, 4(1), 89-102.

Sanjaya (2008). Faktot-Faktor yang Mempengaruhi Hasil Belajar. Jakarta: Prenada.

Satriani, I., Emilia, E., \& Gunawan, M.H. (2012). Contextual teaching and learning approach to teaching writing. Indonesian Journal of Applied Linguistics, 2(1), 10-22.

Santrock, J.W. (2011). Educational Psychology (5th ed). New York, NY: McGraw-Hill.

Subekti, Y., \& Ariswan, A. (2016). Pembelajaran fisika dengan metode eksperimen untuk meningkatkan hasil belajar kognitif dan keterampilan proses sains. Jurnal Inovasi Pendidikan IPA, 2 (2), 252 - 261.

Suherman (2013). Meningkatkan hasil belajar siswa dengan menggunakan model pembelajaran problem solving berbasis eksperimen dalam pembelajaran Fisika. Jurnal Pendidikan Fisika, 2(2), 57-64. http://jurnal.unimed.ac.id/2012/index.php/jpf

Wibowo, I dan Thung J.L (2010). Setelah Air Mata Kering - Masyarakat Tionghoa Pasca Peristiwa Mei 1998. Jakarta: Kompas Penerbit Buku. 